\title{
Dystrophin in a Membrane Skeletal Network: Localization and Comparison to Other Proteins
}

\author{
George M. Dmytrenko, ${ }^{1}$ David W. Pumplin,, ${ }^{2}$ and Robert J. Bloch ${ }^{3}$ \\ Departments of ${ }^{1}$ Neurology, ${ }^{2}$ Anatomy, and ${ }^{3}$ Physiology, University of Maryland School of Medicine, \\ Baltimore, Maryland 21201
}

\begin{abstract}
We studied the location, relative abundance, and stability of dystrophin in clusters of ACh receptors (AChRs) isolated from primary cultures of neonatal rat myotubes. Although variable amounts of dystrophin were found at receptor clusters, dystrophin was always associated with organized, receptor-rich domains (AChR domains). Dystrophin was occasionally seen in focal contact domains, but never in clathrin-coated domains. Dystrophin was also present in a diffuse, punctate distribution in regions of myotube membrane that did not contain AChR clusters. Immunogold labeling at the ultrastructural level localized dystrophin in a spectrin-rich filamentous network closely applied to the cytoplasmic surface of the cell membrane at AChR domains. Dystrophin was not associated with overlying actin filaments. Semiquantitative immunofluorescence studies indicated that dystrophin was present in relatively small amounts in these preparations, with only one molecule of dystrophin for every $\sim 5$ AChR, $43 \mathrm{kDa}$ and $58 \mathrm{kDa}$ molecules, and for every $\sim 20-35$ $\beta$-spectrin molecules. Clusters were disrupted, but the total amount of dystrophin was not significantly reduced, when myotubes were incubated with sodium azide or in $\mathrm{Ca}^{2+}$-free medium, and when isolated AChR clusters were extracted at low ionic strength, at high $\mathrm{pH}$, or in $6 \mathrm{M}$ urea. These treatments extract other peripheral membrane proteins from AChR clusters. Labeling for dystrophin was completely eliminated when clusters were incubated with chymotrypsin, however. Thus, dystrophin forms part of a membrane skeleton at AChR clusters, but it is more difficult to remove than other proteins in the network. This suggests that dystrophin attaches to cluster membrane in a unique way.
\end{abstract}

[Key words: ACh receptor, cytoskeleton, dystrophin, membrane skeleton, spectrin]

A molecular deficit in Duchenne's muscular dystrophy (DMD) has been defined at the DNA and protein levels (see Hoffman and Kunkel, 1989, for review). The DMD gene encodes a 14

\footnotetext{
Received Apr. 30, 1992; revised July 7, 1992; accepted July 14, 1992.

We thank Drs. Louis Kunkel and Eric Hoffman, Benjamin Geiger, Stanley Froehner, and Mr. Teji Khurana for sharing antibodies, fusion proteins, and technical advice. Debbie Parks, Andrea O’Neill, Wendy Resneck, Nancy Strakna, John Strong, and John White provided expert technical assistance. This research was supported by grants from the National Institutes of Health (NS 15513 to D.W.P. and NS 17282 to R.J.B.) and by grants from the Muscular Dystrophy Association to R.J.B. and D.W.P. G.M.D. is recipient of an NIH Clinical Investigator Development Award (NS 01255).

Correspondence should be addressed to Robert J. Bloch, Department of Physiology, University of Maryland School of Medicine, 660 West Redwood Street, Baltimore, MD 21201.
}

Copyright (c) 1993 Society for Neuroscience $0270-6474 / 93 / 130547-12 \$ 05.00 / 0$ kilobase mRNA that is translated to form a $427 \mathrm{kDa}$ protein termed dystrophin. Dystrophin is organized into four domains: an amino terminal domain homologous to the actin-binding domain of $\alpha$-actinin; a long, slender, rod-shaped domain similar to that of spectrin; a cysteine-rich domain resembling the carboxy terminus of $\alpha$-actinin; and a unique carboxy-terminal domain (Koenig et al., 1988). These similarities suggest that dystrophin may serve a function in skeletal muscle similar to that of $\alpha$-actinin in contractile structures, or of spectrin in the membrane skeleton.

Dystrophin has been detected immunohistochemically at the cytoplasmic surface of the sarcolemma of skeletal muscle (Watkins et al., 1988; Zubrzycka-Gaarn et al., 1988; Wakayama et al., 1989; Carpenter et al., 1990; Cullen et al., 1990; Byers et al., 1991; Porter et al., 1992), in the same region occupied by proteins such as spectrin, ankyrin, and vinculin (Craig and Pardo, 1983; Pardo et al., 1983a,b; Nelson and Lazarides, 1984). Thus, dystrophin is appropriately placed to form part of the muscle membrane skeleton. A recent report confirms the localization of dystrophin in a subsarcolemmal array of filaments (Wakayama and Shibuya, 1991).

In an effort to elucidate the cellular role of dystrophin, investigators have searched for structures other than the sarcolemma that are rich in this protein. Their studies have revealed that dystrophin is present at the $\mathrm{ACh}$ receptor (AChR)-rich membranes of Torpedo electric organ (Chang et al., 1989; Jasmin et al., 1990), at vertebrate neuromuscular junctitons (Shimizu et al., 1989; Sealock et al., 1991; Yeadon et al., 1991), and at synapses within the CNS (Lidov et al., 1990). An analog of dystrophin, termed "dystrophin-related protein" or DRP (Love et al., 1989; Khurana et al., 1990), is also concentrated at the neuromuscular junctions of normal and dystrophin-less vertebrates (Fardeau et al., 1990; Ohlendieck et al., 1991a; Pons et al., 1991). These reports suggest that dystrophin and DRP may be important macromolecules at the synapse as well as elsewhere on the sarcolemma.

We have studied dystrophin in AChR-rich membranes of culturcd nconatal myotubes. Cultured myotubes form clusters of AChRs where the cell membrane adheres to the substrate (Land et al., 1977; Bloch and Geiger, 1980; Axelrod, 1981). Detergent extraction or physical shearing of cultured myotubes yields a preparation of substrate-associated membrane (SAM) that is enriched in AChR clusters (Bloch, 1984; Pumplin, 1989), identifiable with fluorescent conjugates of $\alpha$-bungarotoxin. The membrane and subjacent cytoskeleton of clusters are highly organized into characteristic receptor-rich and receptor-poor domains (Bloch and Geiger, 1980; Pumplin and Bloch, 1983). The receptor-rich, $\mathrm{AChR}$ domains resemble the membrane of the human erythrocyte, with AChR associated with a spectrin-rich 
membrane skeletal network (reviewed in Bloch and Pumplin, 1992). The receptor-poor domains are involved in attaching the membrane to the substrate and are organized as either focal contacts (Bloch and Geiger, 1980; Bloch et al., 1989; Pumplin, 1989) or as large plaques of clathrin-coated membrane (Pumplin, 1989; Pumplin and Bloch, 1990). Thus, isolated AChR clusters are a suitable preparation with which to study the ability of dystrophin to associate with different membrane-cytoskeletal structures.

We report here that variable amounts of dystrophin are present at AChR clusters. Within these clusters, dystrophin is enriched at the receptor-rich, AChR domains and is only rarely present at AChR-poor, "contact" domains. Ultrastructural studies show that dystrophin in these receptor-rich domains is part of a filamentous network, composed largely of spectrin (Bloch and Morrow, 1989; Pumplin et al., 1990), that is closely applied to the membrane. Although dystrophin is present in significantly smaller amounts than other peripheral membrane protcins of AChR clusters, it is bound to cluster membrane more stably than these proteins.

\section{Materials and Methods}

Neonatal myotube culture. Muscle cells were isolated from hind limbs of neonatal Sprague-Dawley rats, as described previously (Bloch, 1979; Bloch and Geiger, 1981) and cultured on borosilicate glass coverslips (no. 1 thickness; VWR Scientific, Bridgeport, NJ) in Dulbecco-Vogt modified Eagle's medium (DMEM; GIBCO, Grand Island, NY) supplemented with $10 \%$ fetal calf serum. In some cases, cells were grown on larger ( $8 \mathrm{~cm}$ diameter) coverslips cut from sheets of coverslip glass (no. 1.5 thickness; Erie Scientific, Erie, PA). Cultures, 6-8 d old, were stained for $30 \mathrm{~min}$ at room temperature $\left(\mathrm{RT} ; 22^{\circ} \mathrm{C}\right.$ ) with tetramethylrhodamine- $\alpha$-bungarotoxin (R-BT), prepared as previously reported (Ravdin and Axelrod, 1977), and diluted to a final concentration of 5 $\mu \mathrm{g} / \mathrm{ml}$ in HEPES-buffered DMEM supplemented with $5 \%$ fetal calf serum.

Isolation of $A C h R$ clusters. Myotube cultures were extracted with saponin as previously described (Bloch, 1984). Briefly, cultures were washed at RT once with phosphate-buffered saline (PBS), and once with PBS containing $10 \mathrm{mM} \mathrm{MgCl}_{2}, 1 \mathrm{~mm}$ EGTA, and $1 \%(\mathrm{w} / \mathrm{v})$ BSA. Cultures were then placed in the latter solution supplemented with $0.2 \%$ saponin, and gently shaken for $<10 \mathrm{~min}$ at RT on a Luckham 802 suspension mixer (Tekmar Co., Cincinnati, $\mathrm{OH}$ ), until cellular material was shed from the coverslip. For isolation by shearing, cultures were treated for 2 min with a solution containing $\mathrm{ZnCl}_{2}(1 \mathrm{~mm} \mathrm{ZnCl}, 3 \mathrm{~mm}$ EGTA, 5 $\mathrm{mM} \mathrm{MgCl}_{2}, 100 \mathrm{~mm}$ PIPES, pH 6.0; Avnur and Geiger, 1981), and then sheared with a stream of buffer containing a high concentration of $\mathrm{K}^{+}$ (100 mM KCl, $5 \mathrm{~mm} \mathrm{MgCl}$, $3 \mathrm{~mm}$ EGTA, $20 \mathrm{~mm}$ HEPES, pH 7.0; Aggeler and Werb, 1982). Material remaining bound to coverslips, consisting of SAM enriched in AChR clusters, was fixed in paraformaldehyde, or treated further and then fixed. Fixed samples were incubated in $0.1 \mathrm{M}$ glycine to inactive remaining free aldehydes and subsequently washed in PBS supplemented with $1 \%$ BSA (PBS/BSA).

Incubation and extraction of $A C h R$ clusters. Some myotube cultures were treated with medium containing $5 \mathrm{~mm}$ azide or in $\mathrm{Ca}^{2+}$-free medium for $6 \mathrm{hr}$ prior to detergent extraction. Both treatments have been shown to disrupt AChR clusters and associated cytoskeletal elements (Bloch, 1979, 1983, 1986; Bursztajn et al., 1984; Bloch and Morrow, 1989). Other detergent-isolated SAM preparations were treated with buffers that remove various cytoskeletal components. Some samples were transferred serially through two volumes of PBS or buffer A ( $2 \mathrm{~mm}$ Tris- $\mathrm{HCl}, 0.2 \mathrm{~mm} \mathrm{ATP}, \mathrm{pH} 8.0$ ), incubated for $10 \mathrm{~min}$ in $3 \mathrm{ml}$ of the same solution, and then fixed. Buffer A (Spudich and Watt, 1971) selectively extracts actin from SAM (Bloch, 1986). Other samples were treated at RT at high ionic strength $(0.6 \mathrm{M} \mathrm{KCl})$, in alkaline buffer $(50$ mM ethylamine- $\mathrm{HCl}, \mathrm{pH} 11$ ), with lithium diiodosalicylate (LIS; $20 \mathrm{~mm}$ LIS, $10 \mathrm{~mm} \mathrm{NaP,} 1 \mathrm{~mm}$ EDTA, 1 mм EGTA, pH 7.2), $6 \mathrm{~m}$ urea, or chymotrypsin $(0.1 \mathrm{U} / \mathrm{ml})$ in PBS, for $5 \mathrm{~min}$. Control samples were incubated in PBS or with chymotrypsin inactivated by heating or by the addition of $0.1 \mathrm{~mm}$ phenylmethylsulfonyl fluoride.

Antibodies. Crude sheep antiserum or affinity-purified antibodies against the trpE $+60 \mathrm{kDa}$ fusion protein (sheep anti-dystrophin, a gift from Dr. Louis Kunkel, Harvard Medical School, Boston), and monoclonal antibodies (mAbs) to Torpedo dystrophin (mAbs 1808 and 1958, gifts of Dr. Stanley Froehner, School of Medicine, University of North Carolina, Chapel Hill, NC) were used for immunohistochemistry. Affinity purification followed the method described by Hoffman et al. (1987). Specificities of the crude antiserum, the affinity-purified polyclonal antibody, and the monoclonal antibodies were demonstrated by immunoblotting extracts of bacteria containing the trpeE expression vector or the trpE $+60 \mathrm{kDa}$ fusion protein, or of the Triton X-100insoluble fraction of homogenized rat hind limb muscle. These antibodies recognized a high-molecular-weight band of $>400 \mathrm{kDa}$ in immunoblots of rat skeletal muscle (Porter et al., 1992). mAbs 1808 and 1958 have been previously characterized and recognize the same highmolecular-weight band identified by sheep anti-dystrophin (Sealock et al., 1991; Porter et al., 1992).

The anti-dystrophin antibodies were specific for dystrophin and did not react with dystrophin-related protein, by two assays. (1) In immunoblotting, both sheep anti-dystrophin and $\mathrm{mAb} 1808$ reacted exclusively with a closely spaced doublet at $\sim 400 \mathrm{kDa}$ in normal rat and mouse muscle, but not in muscle from the $m d x$ mouse (Porter et al., 1992), which lacks dystrophin (Bulfield et al., 1984; Hoffman et al., 1987,1988 ) but contains DRP (Love et al., 1989; Khurana et al., 1990). (2) Immunofluorescence labeling of cryostat sections showed that normal rat and mouse muscles were labeled with both anti-dystrophin antibodies at the neuromuscular junction and at extrajunctional sarcolemma, but $m d x$ muscles were not. These results agree with reports from other laboratories (Arahata et al., 1988; Bonilla et al., 1988; Zubrzycka-Gaarn et al., 1988; Sealock et al., 1991).

Immunofluorescence microscopy. Samples were incubated for 0.5-1 $\mathrm{hr}$ in solutions of primary antibody (sheep anti-dystrophin antiserum, diluted 1:4000; affinity purified anti-dystrophin antibody, diluted $1: 1000 ; \mathrm{mAbs} 1808$ or $1958,10 \mu \mathrm{g} / \mathrm{ml}$ ). Samples were washed three times in PBS/BSA and incubated for $30 \mathrm{~min}$ with biotinylated donkey anti-sheep IgG (BDASh), biotinylated goat anti-mouse IgG (BGAM), fluoresceinated donkey anti-sheep IgG (FDASh), or fluoresceinated goat anti-mouse IgG (FGAM), all diluted 1:100. Samples labeled with BDASh or BGAM were visualized with fluorescein streptavidin (FSav; diluted 1:250). Some samples incubated with FGAM were labeled further with fluoresceinated rabbit anti-goat IgG (TRAG; diluted 1:100) to enhance the fluorescent signal. Coverslips were mounted in $90 \%$ glycerol, $10 \%$ $1 \mathrm{M}$ Tris- $\mathrm{HCl}, \mathrm{pH} 8.0$, supplemented with $1 \mathrm{mg} / \mathrm{ml} p$-phenylenediamine (Johnson et al., 1982), and observed through a Zeiss PlanApo $63 \times /$ NA 1.4 or PlanNeofluar $63 \times / \mathrm{NA} 1.25$ oil immersion objective on a Zeiss IM 35 or Axioplan microscope. Photomicrography employed Ilford HP 5 film, exposed for 15-60 sec and processed at ASA 1600 using Ilford Microphen developer (Ilford, Basildon, Essex, UK), or Kodak TMax P3200 film exposed for 5-20 sec and processed to ASA 3200 using Kodak TMax developer (Eastman, Rochester, NY).

Enzyme-linked immunosorbent assay (ELISA). Plastic 96-well dishes (Immulon II, Dynatech Laboratories, Alexandria, VA) were coated with $75 \mu \mathrm{l}$ aliquots of FGAM $(10 \mathrm{ng} / \mathrm{ml}$ in PBS). Additional protein binding sites were blocked with saturating amounts of BSA and $1 \%$ normal goat serum diluted in PBS. Wells were incubated with increasing concentrations of $\mathrm{mAb} 1808$, or with $\mathrm{mAb} 88 \mathrm{~B}$ (Froehner et al., 1983). Binding of $\mathrm{mAbs} 1808$ and $88 \mathrm{~B}$ to the wells was detected with saturating concentrations of donkey anti-mouse antibodies conjugated to alkaline phosphatase followed by incubation with $p$-nitrophenyl phosphate.

ELISA showed that FGAM captures mAbs 1808 and 88B equally well: binding of both $\mathrm{mAbs}$ saturates at 0.55 and shows an apparent half-maximum at $7 \mathrm{ng} \mathrm{mAb} / \mathrm{ml}$ (not shown), similar to previous reports for 88B (Bloch et al., 1991).

Semiquantitative immunofluorescence. Samples were observed with a Zeiss IM-35 microscope equipped for epifluorescence and a photomultiplier for semiquantitative measurements. The incident illumination was limited to a region of the sample $5 \mu \mathrm{m}$ in diameter, and the fluorescence from this region was measured with the photomultiplier connected to an $I$-to- $V$ converter (see Bloch, 1986, for details). Measurements of fluorescein fluorescence $(F)$ due to bound antibody, and of tetramethylrhodamine fluorescence $(R)$ due to bound R-BT, were always made from the same area. Mean values of $F$ and of the ratio, $F / R$, were calculated after background was subtracted.

To obtain more reliable semiquantitative data, we often amplified the signal generated by the anti-dystrophin antibodies by using a tertiary fluoresceinated antibody, or by using a biotinylated secondary antibody 
followed by FSav (see above). We checked that these amplification methods gave reliable results by using them with the anti-AChR mAb 88B (Froehner et al., 1983). Compared to FGAM alone, BGAM followed by FSav increased the $F$ and $F / R$ values afforded by bound $\mathrm{mAb}$ $88 \mathrm{~B}$ by approximately twofold, whereas FGAM followed by FRAG increased these values four- to fivefold. These values increased proportionately when isolated clusters were extracted at alkaline $\mathrm{pH}$ (Table 1 ), which approximately doubles the $F / R$ ratios obtained with $\mathrm{mAb}$ 88B and FGAM alone (Bloch and Froehner, 1987). Extraction at alkaline $\mathrm{pH}$ followed by digestion with chymotrypsin completely eliminates labeling by $\mathrm{mAb} 88 \mathrm{~B}$ and FGAM (Table 1; Bloch and Froehner, 1987). Amplification with BGAM and FSav or FGAM and FRAG did not change this result. Both methods, therefore, reliably increased our signal without significantly altering the quantitative differences among samples.

Ultrastructural methods. Quick-freeze, deep-etch, rotary-replication (QFDERR; see Heuser and Kirchner, 1980) and immunogold labeling of clusters were performed as described previously (Pumplin, 1989; Pumplin and Bloch, 1990; Pumplin et al., 1990). In brief, clusters isolated by shearing and fixed in paraformaldehyde were labeled with affinity-purified sheep anti-dystrophin for $1 \mathrm{hr}$ at RT, washed in PBS/ BSA, and then incubated with rabbit anti-sheep IgG for $1 \mathrm{hr}$ at RT. After washing, the samples were incubated overnight at $4^{\circ} \mathrm{C}$ with goat anti-rabbit IgG adsorbed to $10 \mathrm{~nm}$ colloidal gold (Janssen Pharmaceuticals, Beerse, Belgium) diluted 1:10 in BANT $(1 \% \mathrm{BSA}, 0.5 \mathrm{M} \mathrm{NaCl}$, $20 \mathrm{~mm}$ Tris, $10 \mathrm{~mm} \mathrm{NaN}_{3}$, pH 7.4; Luther and Bloch, 1989). For double labeling with immunogold, isolated clusters were incubated serially with sheep anti-dystrophin (diluted 1:2000 in PBS/BSA), mAb VIIF7 anti$\beta$-spectrin (Bloch and Morrow, 1989; diluted 1:50), and rabbit antisheep IgG (diluted 1:100) for $1 \mathrm{hr}$ each at RT. Samples were washed thoroughly between each incubation, and then washed in BANT and serially labeled with goat anti-rabbit IgG adsorbed to $5 \mathrm{~nm}$ colloidal gold and goat anti-mouse IgG adsorbed to $10 \mathrm{~nm}$ colloidal gold. Each incubation was for overnight at $4^{\circ} \mathrm{C}$.

Well-formed clusters were chosen by R-BT fluorescence. They were photographed, and their positions were marked with a diamond marking objective. Concentric circles around the marked clusters were cut from the coverslips. Samples were fixed further in $2 \%$ glutaraldehyde, and then rinsed three times in PBS followed by a rinse in $\mathrm{D}_{2} \mathrm{O}$. After removal of nearly all the overlying liquid, the samples were rapidly frozen against a polished copper anvil cooled to $-196^{\circ} \mathrm{C}$. Frozen samples were freeze dried at $-95^{\circ} \mathrm{C}$ under high vacuum until $\mathrm{D}_{2} \mathrm{O}$ emission ceased, and then rotary-replicated with platinum applied at an angle of $20^{\circ}$; a backing layer of carbon was applied at an angle of $90^{\circ}$. Replicated clusters were relocated by referring to the previously scribed circles. They were floated off the coverslips in 5\% hydrofluoric acid, rinsed in water, and picked up on Formvar-coated slot grids. Electron micrographs were taken at low magnification $(1500 \times)$ to compare with corresponding fluorescence micrographs. High-magnification views of AChR domains were taken at $45,000 \times$ in stereo pairs with $\pm 6^{\circ}$ of tilt. These areas were identified by their location in areas with intense R-BT labeling and by their characteristic ultrastructure.

Quantitation of immunogold labeling. To count gold particles in AChR domains of myotubes, one negative of a stereo pair was printed at $2.5 \times$ magnification. The stereo pair of negatives was then transilluminated and viewed at $4 \times$ magnification in a mirror stereoscope (Ladd Research Industries, Burlington, VT). Gold particles resulting from dystrophin labeling appeared in discrete groups lying on the membrane-associated network of filaments. For each group, the total number of gold particles and the number of gold particles that were within $20 \mathrm{~nm}$ (edge to edge) of an actin filament were counted and recorded on the photographic print. The areas occupied by the membrane-associated network alone, and by the network with overlying actin filaments, were measured stereologically, using the mirror stereoscope to view the stereo pair of negatives and an overlying grid of test points spaced $6 \mathrm{~mm}$ apart (304 test points per negative). Counts of gold particles were compared to the relative area of micrographs $(n=13)$ containing either actin or the membrane meshwork using the following ratios:

no. gold particles $<20 \mathrm{~nm}$ from actin filaments total no. gold particles

and

no. test points overlying both actin filaments and network no. test points overlying network
Table 1. Two methods of fluorescent signal amplification preserve quantitative detection of an antigen

\begin{tabular}{lccc} 
& \multicolumn{3}{l}{ Method $(F / R)$} \\
\cline { 2 - 4 } Treatment $^{a}$ & FGAM & BGAM/FSav & FGAM/FRAG \\
\hline PBS (control) & $1.09 \pm 0.1$ & $1.86 \pm 0.34$ & $4.67 \pm 0.61$ \\
& $(1)^{b}$ & $(1)$ & $(1)$ \\
pH 11 & $2.89 \pm 0.25^{*}$ & $4.94 \pm 0.87^{*}$ & $14.6 \pm 2.22^{*}$ \\
& $(2.6)$ & $(2.6)$ & $(3.1)$ \\
pH 11+CT & $0.03 \pm 0.01^{*}$ & $0.16 \pm 0.05^{*}$ & $0.34 \pm 0.12^{*}$ \\
& $(0.03)$ & $(0.09)$ & $(0.07)$
\end{tabular}

Myotubes were labeled with R-BT and extracted with saponin to isolate $\mathrm{AChR}$ clusters. Isolated clusters were treated with PBS or $50 \mathrm{~mm}$ ethylamine, $\mathrm{pH} 11$. Samples were then fixed immediately or digested further with $0.1 \mathrm{U} / \mathrm{ml}$ chymotrypsin in PBS and then fixed. All samples were labeled with $25 \mathrm{nM}$ anti-AChR $\mathrm{mAb} 88 \mathrm{~B}$ followed by one of three combinations of secondary and tertiary fluorescent reagents. Measurement of fluorescein fluorescence $(F)$ due to bound antibody, and of tetramethylrhodamine fluorescence $(R)$ due to bound R-BT were made from the same area and the ratio $F / R$ was calculated.

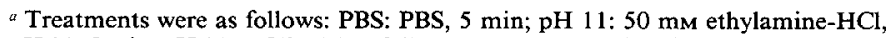
$\mathrm{pH} 11,5 \mathrm{~min} ; \mathrm{pH} 11+\mathrm{CT}: \mathrm{pH} 11$ followed by $10 \mu \mathrm{g} / \mathrm{ml}$ digestion in chymotrypsin for $5 \mathrm{~min}$. All treatments were at RT.

${ }^{h}$ The numbers in parentheses represent the factor increase or decrease in $F / R$ values seen following $\mathrm{pH} 11$ or $\mathrm{pH} 11+\mathrm{CT}$ treatments, compared to controls. $F / R$ ratios are reported as means $\pm \mathrm{SD} ; n=10$.

* Significantly different from control, $p<0.01$ by ANOVA.

We used the same techniques to count gold particles at focal contact domains of the same myotubes; these were identified as membrane regions overlain by bundles of parallel actin filaments. Stereo views of focal contact domains showed that most of the gold particles occurred in groups lying close to the membrane, and were beneath the overlying actin filaments. To examine the specificity of labeling, we counted gold particles on replicas of clusters immunolabeled with the usual procedure except that BSA or normal sheep serum replaced the primary antibody. We also counted gold particles on areas of the substrate and at focal contacts of nearby fibroblasts in replicas of clusters immunolabeled with anti-dystrophin.

Statistical methods. Semiquantitative immunofluorescence data were analyzed by ANOVA. Quantitative data from immunogold labeling were analyzed by two-tailed Student's $t$ test.

Materials. $\mathrm{Ca}^{2+}$-free DMEM was prepared in our laboratory. Fetal calf serum was dialyzed extensively against $\mathrm{PBS}$ to remove $\mathrm{Ca}^{2+}$. The final concentration of $\mathrm{Ca}^{2+}$ in the medium was $<25 \mu \mathrm{M}$, as determined by atomic absorption spectroscopy. Monoclonal antibody to vinculin, mAb 11.5, was a gift from Dr. Benjamin Geiger (Weizman Institute, Rehovot, Israel). Secondary antibodies and fluorescent reagents were purchased from Jackson Immunoresearch (West Grove, PA). All other materials were purchased from Sigma Chemical Company (St. Louis, MO).

\section{Results}

\section{Dystrophin in isolated $A C h R$ clusters}

We studied dystrophin in SAM isolated from cultured myotubes. SAM contains many large clusters of AChRs, which are easily identified with fluorescent derivatives of $\alpha$-bungarotoxin. These clusters are organized into alternating, linear, receptorrich "AChR domains" and receptor-poor "contact domains" (Fig. 1A,C,E). When SAM was stained with sheep anti-dystrophin antibody or anti-dystrophin mAbs 1808 or 1958, followed by FDASh or FGAM, respectively, the fluorescent labeling at AChR clusters was weak. We enhanced the fluorescent signal either by using secondary antibodies conjugated to biotin and fluoresceinated streptavidin, or by adding two fluoresceinated antibodies sequentially (FGAM followed by FRAG). After such enhancement, dystrophin was easily and specifically detected at AChR clusters. No fluorescent label was seen when primary 

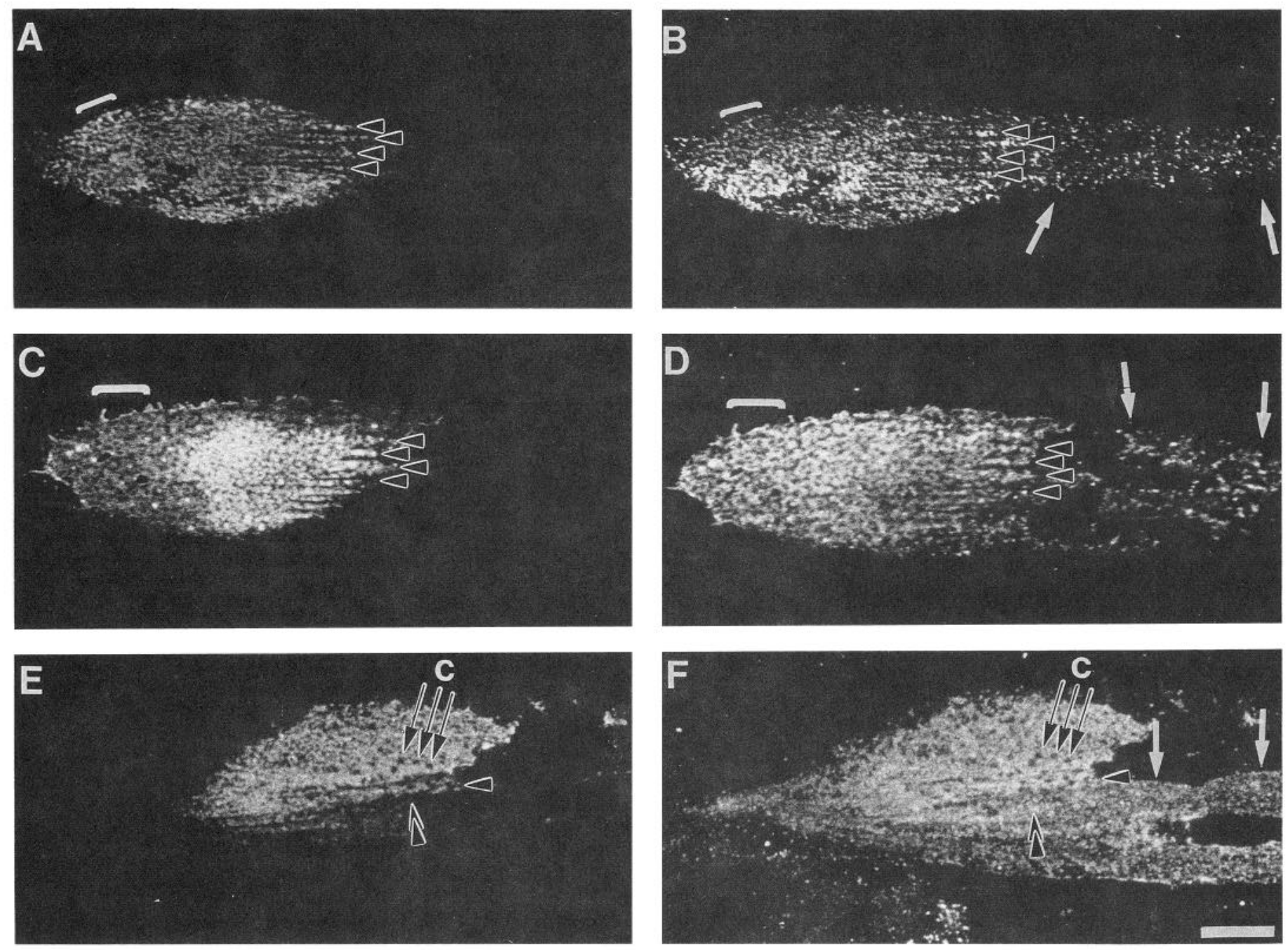

Figure 1. Dystrophin is associated with AChR clusters isolated from cultured neonatal myotubes. Rat myotubes were prelabeled with R-BT and subjected to detergent extraction $(A, B)$ or physical shearing $(C-F)$ to isolate SAM. Samples were fixed and labeled with affinity-purified antidystrophin antibody, incubated with a biotinylated secondary antibody, and visualized with fluoresceinated streptavidin $(B, D, F)$. Variable amounts of dystrophin label were found at receptor clusters (brackets in $A-D$ ), but dystrophin tended to colocalize with R-BT label within AChR-rich domains (single arrowheads, $A-F$ ). Dystrophin label was absent from clathrin-coated membrane domains (typically found in oval or circular areas, such as black arrows labeled $c$ in $E, F$ ), but was occasionally seen in focal contact domains (double arrowheads in $E, F$ ). In regions of SAM lacking AChR clusters (between white arrows in $B, D, F$ ), dystrophin label was scattered and punctate. Scale bar, $10 \mu \mathrm{m}$.

antibodies were omitted from the staining protocol. Appropriate controls showed that the fluorescence intensities obtained with enhancement accurately reflected relative changes in a membrane-bound antigen (see Materials and Methods; Table 1).

When we used these enhancement techniques, we found that dystrophin label was usually concentrated in the AChR domains, but that the intensity of staining there varied greatly (Fig. $1 B, D, E$; see below). Dystrophin was seen only rarely in contact domains, and when present, it appeared only at focal contact domains associated with microfilaments (see below) and not at contact domains rich in clathrin. Dystrophin labeling was also seen in a diffuse punctate pattern in receptor-poor regions and on fragments of myotube membrane free of $\mathrm{AChR}$ clusters (Fig. $1 B, D, E)$.

\section{Ultrastructural localization of dystrophin in AChR clusters}

We used anti-dystrophin antibodies to localize dystrophin in AChR clusters at the ultrastructural level. In clusters isolated by shearing with a stream of buffer, QFDERR reveals two cy- toskeletal components of these domains: a network of short filaments closely applied to the cytoplasmic surface of the membrane and longer actin filaments that lie over this network (Pumplin, 1989). We used immunogold labeling followed by QFDERR to localize dystrophin with respect to these cytoskeletal components. We deliberately chose regions of AChR clusters for these studies with a relatively high content of dystrophin.

Immunogold labeling for dystrophin appeared preferentially in AChR domains identified by R-BT fluorescence; stereo electron micrographs showed that gold particles within these domains formed small clusters on the filamentous network applied to the membrane and did not appear to decorate the overlying actin filaments (Fig. 2). Thus, immunogold labeling for dystrophin confirmed and extended the results from immunofluorescent labeling that showed dystrophin colocalizing with AChR in myotubes.

Quantification of immunogold labeling showed that dystrophin labeling was specific and confined to myotubes in our cultures. Few gold particles were found on plaques of polymer- 

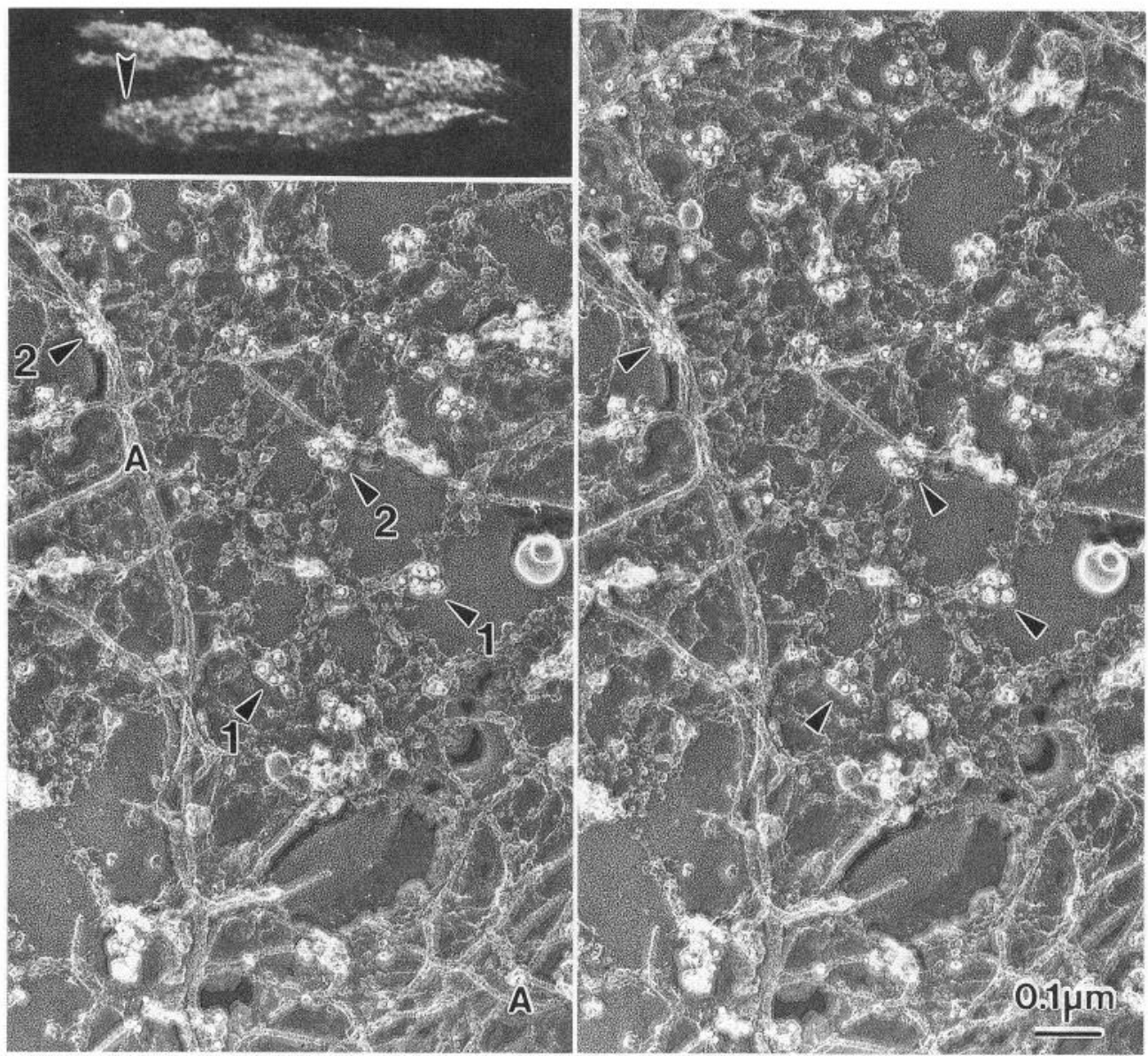

Figure 2. Antibodies to dystrophin bind to the membrane-associated network of filaments at $\mathrm{AChR}$ domains, not to actin filaments. An AChR cluster was labeled with R-BT, isolated by shearing, and then visualized by fluorescence microscopy followed by immunogold labeling and QFDERR (see Materials and Methods for details) AChR domains were identified with R-BT (upper panel) and corresponding portions of the replica were examined in the electron microscope. The replica shown in the lower panels is from the brightly fluorescent area at the tip of the arrowhead in the upper panel, and it thus represents an area rich in AChR. A network of short intersecting filaments closely applied to the cytoplasmic face of the ventral membrane is decorated by gold particles (arrowheads), marking sites of binding of anti-dystrophin antibodies. Gaps in this relatively loose network of filaments expose the cytoplasmic surface of the membrane, which is not labeled by gold particles. The majority of gold particles decorate a membrane-associated network without decorating any overlying actin filaments (arrowheads 1). When actin filaments are present $(A)$, only a small number (two or three) of the gold particles in a group are within $20 \mathrm{~nm}$ of the filament (arrowheads 2). In all such cases, the gold particles were beside or below the overlying actin filaments; this propinquity was coincidental (see Results). ized clathrin (not shown), on the substrate, or on the replicated membranes of fibroblasts. Very few gold particles were seen if normal sheep serum was substituted for the primary antibody, or if the primary or secondary antibodies were omitted from the labeling procedure (Table 2).
In AChR clusters chosen for their relatively high content of dystrophin label, dystrophin was nearly six times more prevalent at AChR domains than at adjacent contact domains of the same myotube (Table 2). At both AChR and contact domains, labeling occurred on material lying on the cytoplasmic surface

Table 2. Distribution of immunogold-labeled dystrophin in QFDERR samples of AChR clusters

\begin{tabular}{|c|c|c|c|c|}
\hline Location & Gold particles $/ \mu \mathrm{m}^{2}$ & $\begin{array}{l}\text { Total area } \\
\text { examined }\left(\mu \mathrm{m}^{2}\right)\end{array}$ & \# Areas & \# Replicas \\
\hline \multicolumn{5}{|l|}{ Anti-dystrophin } \\
\hline \multicolumn{5}{|l|}{ AChR cluster } \\
\hline Receptor domain & $145.0 \pm 70.0$ & 28.8 & 13 & 4 \\
\hline Contact domain & $24.6 \pm 12.8^{a}$ & 37.9 & 7 & 1 \\
\hline \multicolumn{5}{|l|}{ Fibroblast } \\
\hline Focal contact & $3.6 \pm 3.6$ & 36.4 & 6 & 2 \\
\hline Substrate & $0.6 \pm 0.3$ & 148.0 & 8 & 3 \\
\hline \multicolumn{5}{|l|}{ Controls } \\
\hline \multicolumn{5}{|l|}{ Normal sheep serum } \\
\hline Cell membrane & $2.1 \pm 0.6$ & 79.6 & 9 & 1 \\
\hline Substrate & $0.8 \pm 0.7$ & 72.7 & 7 & 1 \\
\hline \multicolumn{5}{|l|}{ No primary antibody } \\
\hline Cell membrane & $0.1 \pm 0.1$ & 78.0 & 7 & 1 \\
\hline
\end{tabular}

AChR clusters were isolated by shearing, labeled with anti-dystrophin antibody and a secondary antibody adsorbed to $10 \mathrm{~nm}$ gold particles, and then subjected to QFDERR. Gold particles in AChR and contact domains were counted in electron micrographs from replicas of identified clusters. The areas occupied by these domains were determined by pointcount stereology. Counts of gold particles (mean \pm SD) were highest in AChR-rich domains. Gold particles were also found in focal contact domains, but in significantly lower abundance $(p<0.01, t$ test). Background concentrations of gold particles were found in focal contact domains of fibroblasts and on the culture substrate.

${ }^{a}$ Gold particles viewed by stereoscopy at contact domains of AChR clusters were closely applied to the cytoplasmic surface of the membrane. 
Figure 3. Dystrophin colocalizes with spectrin in the membrane-associated network of filaments at AChR domains. Samples were processed as in Figure 2 but were double labeled for dystrophin and spectrin. The anti-dystrophin antibody was visualized with a secondary rabbit anti-sheep IgG followed by a tertiary goat anti-rabbit IgG adsorbed to $5 \mathrm{~nm}$ gold particles. The anti-spectrin antibody was visualized with a secondary goat anti-mouse IgG adsorbed to $10 \mathrm{~nm}$ gold particles. Use of an intermediary antibody in the labeling protocol accounts in part for the higher concentration of dystrophin labeling compared to that of spectrin. Gold particles mark sites of binding of anti-dystrophin antibodies $(5 \mathrm{~nm}$ particles) and anti-spectrin antibodies (10 $\mathrm{nm}$ particles). These particles decorate a network of short intersecting filaments closely applied to the cytoplasmic face of the ventral membrane. Both sizes of gold particles often appeared in the same group (arrowheads), indicating the colocalization of dystrophin and spectrin within the filamentous meshwork. Long actin filaments $(A)$, which pass above the membrane-associated network, were not labeled by anti-dystrophin or anti-spectrin antibodies (cf. Fig. 2 and Results).
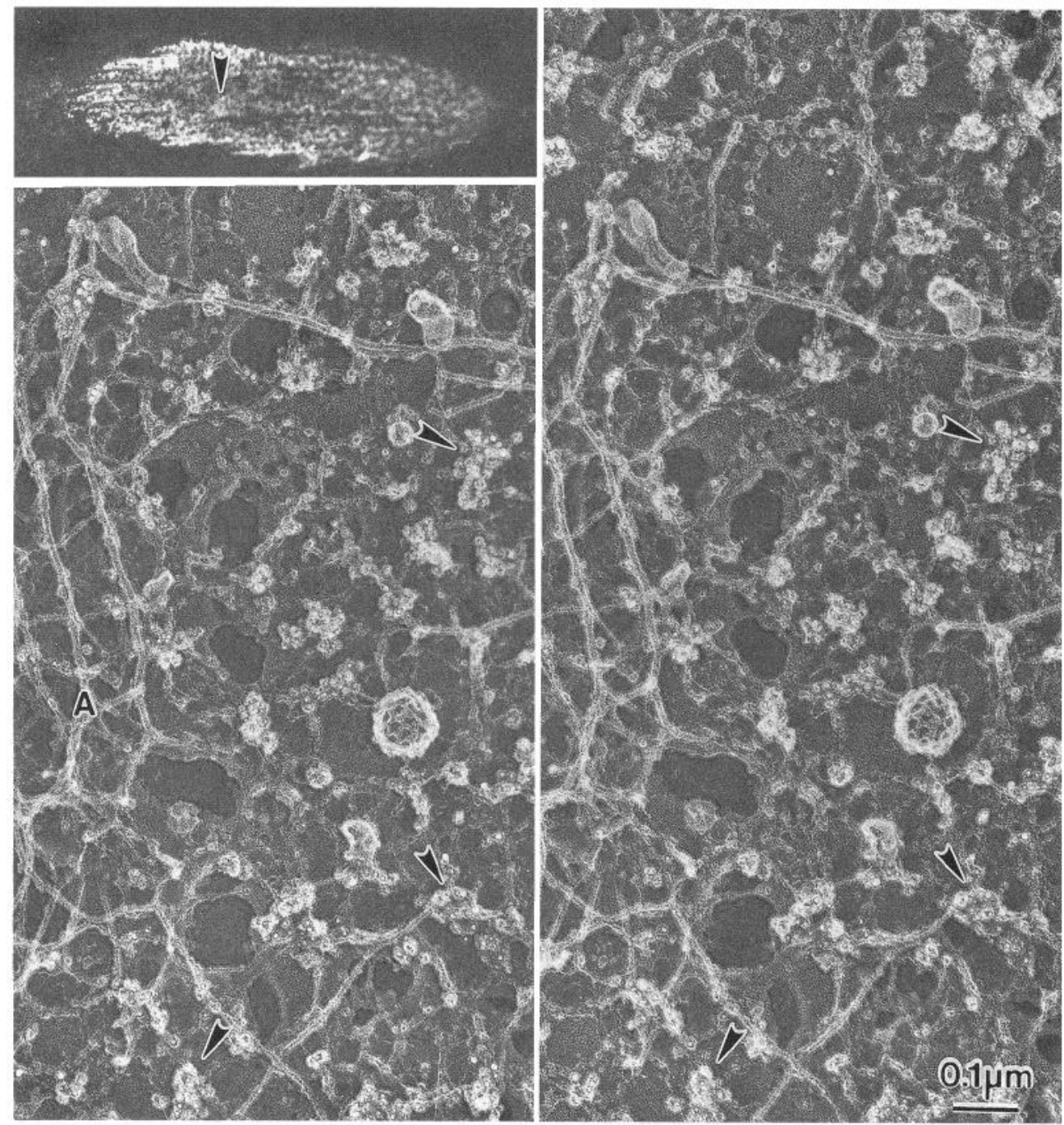

of the membrane. At AChR domains, most gold particles appeared in groups on the network of membrane-associated short filaments characteristic of these domains. However, about 19\% of gold particles at $\mathrm{AChR}$ domains were also close enough to an overlying actin filament to be regarded as possibly being bound indirectly to dystrophin present on the filament. We assessed whether this was purely coincidental by determining the ratio

\section{gold particles close to actin filaments total gold particles at $\mathrm{AChR}$ domains}

and comparing this with the ratio

$$
\frac{\text { area of } \mathrm{AChR} \text { domains containing actin filaments }}{\text { total area of } \mathrm{AChR} \text { domains }} \text {. }
$$

The two ratios, $0.186 \pm 0.050$, and $0.181 \pm 0.048$, were not significantly different ( $p=0.75$, paired $t$ test). Thus, the apparent labeling of overlying actin filaments can be accounted for by coincidence alone. There is no evidence for preferential labeling of these filaments by anti-dystrophin.

The immunofluorescence images and ultrastructural localization of dystrophin within a filamentous network at AChR domains of clusters paralleled similar findings for another cyto- skeletal component plentiful in this filamentous network, $\beta$-spectrin (Bloch and Morrow, 1989; Pumplin et al., 1990). To understand dystrophin's spatial relationship to spectrin within the membrane skeleton, we prepared AChR clusters that were double labeled for dystrophin and for spectrin, reacted them with species-specific anti-antibodies adsorbed to two sizes of colloidal gold, and then subjected the samples to QFDERR. Both sizes of gold particles labeled the membrane-associated filamentous meshwork underlying AChR domains (Fig. 3), showing that, like spectrin, dystrophin is a component of this meshwork.

\section{Semiquantitative immunofluorescence}

We used a semiquantitative immunofluorescence technique with $\mathrm{mAb} 1808$ to estimate the approximate amount of dystrophin present at AChR clusters, following established procedures (Bloch, 1986; Bloch and Froehner, 1987). We labeled AChR clusters with R-BT, isolated them by extraction with saponin or by mechanical shearing, fixed them, labeled them with $\mathrm{mAb}$ 1808 followed by FGAM, and measured the intensities of fluorescein fluorescence $(F)$ and rhodamine fluorescence $(R)$ emitted from areas of clusters $5 \mu \mathrm{m}$ in diameter.

Even at saturating concentrations of mAb 1808 (see below), values of $F$ and of the ratio $F / R$ recorded from AChR clusters 


\begin{tabular}{|c|c|c|c|}
\hline \multirow[b]{2}{*}{ Reagents } & \multicolumn{2}{|c|}{ Primary antibody } & \multirow{2}{*}{$\begin{array}{l}\text { Ratio } \\
1808 / \\
88 B\end{array}$} \\
\hline & 1808 & $88 \mathrm{~B}$ & \\
\hline \multicolumn{4}{|l|}{$F$} \\
\hline FGAM & $0.049 \pm 0.02$ & $0.31 \pm 0.08$ & 0.16 \\
\hline BGAM/FSav & $0.074 \pm 0.02$ & $0.54 \pm 0.11$ & 0.14 \\
\hline FGAM/FRAG & $0.420 \pm 0.13$ & $1.23 \pm 0.24$ & 0.34 \\
\hline \multicolumn{4}{|l|}{$F / R$} \\
\hline FGAM & $0.18 \pm 0.07$ & $1.09 \pm 0.19^{a}$ & 0.17 \\
\hline BGAM/FSav & $0.29 \pm 0.08$ & $1.86 \pm 0.34^{a}$ & 0.16 \\
\hline FGAM/FRAG & $1.74 \pm 0.43$ & $4.67 \pm 0.61^{a}$ & 0.36 \\
\hline
\end{tabular}

AChR clusters were labeled with R-BT, isolated by extraction with saponin, and then fixed and incubated with anti-dystrophin $\mathrm{mAb} 1808$ or with anti-AChR $\mathrm{mAb}$ $88 \mathrm{~B}$. Bound antibody was visualized with one of three combinations of fluoresceinated secondary and terliary reagents (see Table 1 , Materials and Methods). The ratio $F / R$ was calculated from the intensity of fluorescein fluorescence $(F)$ due to bound antibody, and of tetramethylrhodamine fluorescence $(R)$ due to bound R-BT, measured from the same area of membrane. The ratios of $(F) 1808 /$ $(F) 88 \mathrm{~B}$ and $(F / R) 1808 /(F / R) 88 \mathrm{~B}$ indicate that dystrophin is $14-36 \%$ (mean $=$ $22 \%$ ) as abundant as AChRs in AChR clusters.

${ }^{a}$ Data taken from Table 1. The experiments reported in Table 1 and this tablc were performed at the same time.

were low $(F=0.049 \pm 0.02 ; F / R=0.18 \pm 0.02 ;$ mean $\pm \mathrm{SD}$, $n=30$; see Table 3 ). We obtained similar results with clusters isolated by extraction with saponin and by shearing. When we performed similar experiments with $\mathrm{mAbs}$ to $\mathrm{AChR}$ or to the $43 \mathrm{kDa}$ or $58 \mathrm{kDa}$ proteins, we obtained $F / R$ values of approximately 1 for each protein (Bloch and Froehner, 1987; Bloch et al., 1991). FGAM binds to mAb 1808 and to anti-AChR $\mathrm{mAb} 88 \mathrm{~B}$ to the same extent (see Materials and Methods). If we assume that these mAbs bind with the same valency to their respective antigens, then an $F / R$ value of 0.2 for $\mathrm{mAb} 1808$ suggests that $A C h R$ clusters contain only about one dystrophin molecule for every five AChR molecules (see Table 3).

Amplification of the low fluorescent signal obtained with $\mathrm{mAb}$ 1808 gave qualitatively similar results: dystrophin labeling was consistently lower than the amplified signal for AChR (Table 3). The values obtained with FGAM/FRAG amplification for the relative amounts of $\mathrm{mAbs} 1808$ and $88 \mathrm{~B}$ bound at clusters were approximately twice those obtained with BGAM/FSav amplification (Table 3), however. We cannot explain this dis- crepancy, but it does not significantly alter our results. With all three labeling methods, the average values obtained for $\mathrm{mAb}$ 1808 binding to AChR-rich membranes were only 20\% of the level of $\mathrm{mAb} 88 \mathrm{~B}$ binding. These low values are consistent with the faint staining we observed with $\mathrm{mAb} 1808$ and FGAM alone.

The semiquantitative fluorescence measurements showed higher SDs than we have obtained with other antibodies (Bloch and Froehner, 1987; Bloch and Morrow, 1989; Bloch et al., 1991). Although the fluorescein intensity, $F$, due to labeling of dystrophin, was correlated significantly with the rhodamine intensity, $R$, due to labeling of AChR ( $p<0.001, n=40$; not shown), the corrclation cocfficicnt for mAb 1808 was only 0.56 , significantly less than the correlation coefficient of 0.9 obtained with anti-AChR mAb 88B $(p<0.05$; coefficients compared after normalization with the transformation $Z=0.5 \ln [(1+r) /(1-$ $r)$ ]. Thus, the amount of bound R-BT is a better indicator of the amount of bound $88 \mathrm{~B}$ than it is of bound anti-dystrophin. These results confirm our impression that labeling for dystrophin at AChR clusters varied in intensity but tended to concentrate at AChR domains (e.g., Fig. 1, Table 2).

We used fluorescence amplification to quantitate the binding of sheep and mAb 1808 anti-dystrophin antibodies to isolated AChR clusters. The results (Fig. 4) indicate that both antibodies bind to clusters in a saturable manner. The experiments described below employed these antibodies at concentrations close to saturating.

\section{Extraction of dystrophin from $A C h R$ clusters}

We used buffers that remove cytoskeletal proteins from detergent-isolated SAM to assess the stability of binding of dystrophin to cluster membrane. The organization of AChR clusters was disrupted by all of the treatments (Fig. $5 A, C, E$ ). In samples treated with chymotrypsin (Fig. $5 F$ ), the fluorescence intensity due to bound antibodies also decreased, suggesting that dystrophin was removed from the membrane by proteolysis. Other treatments (low ionic strength: Fig. $5 B$; ethylamine buffer, $\mathrm{pH}$ 11: Fig. $5 D ; 6 \mathrm{M}$ urea, and $20 \mathrm{~mm}$ LIS: not shown) redistributed dystrophin but did not remove it from cluster membrane. Semiquantitative fluorescence measurements (Fig. 6, solid bars) confirmed these impressions. We obtained similar results with AChR clusters isolated either by shearing or by extraction with saponin, and sheep anti-dystrophin gave results almost identical to those obtained with mAb 1808 (not shown). In all cases, only pro-
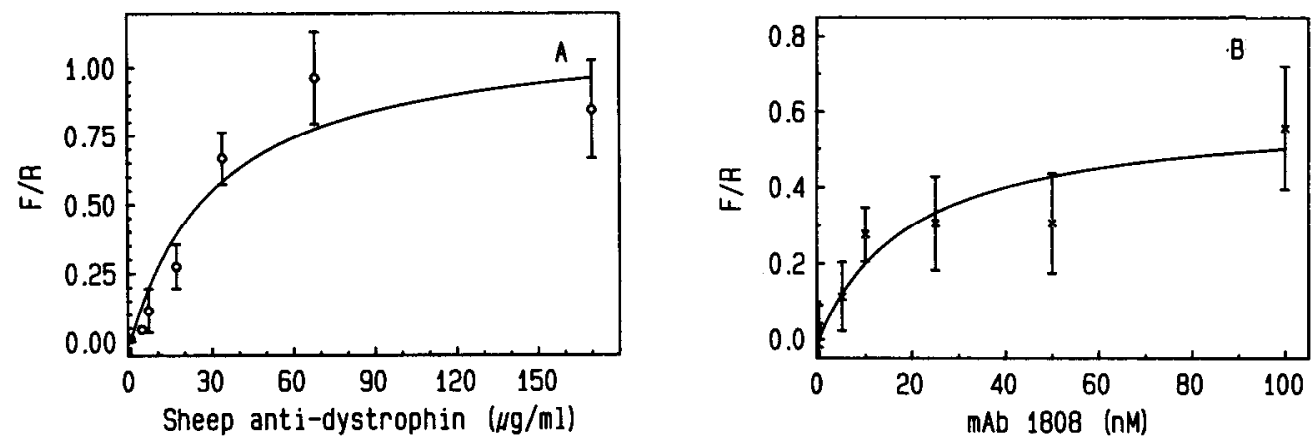

Figure 4. Anti-dystrophin antibodies show saturable binding to AChR clusters. AChR clusters were isolated by extraction with saponin, fixed, and incubated with purified $\mathrm{mAb} 1808$ anti-dystrophin, or with sheep anti-dystrophin antiserum, at increasing concentrations. Samples were incubated further in biotinylated anti-antibodies and fluorescein-streptavidin $(A)$ or with FGAM followed by FRAG $(B)$. The intensities of fluorescein fluorescence $(F)$ due to bound antibody, and of tetramethylrhodamine fluorescence $(R)$ due to bound R-BT were made from the same area, and the ratio $F / R$ was calculated. The data were fit with rectangular hyperbolas with the following constants: sheep antidystrophin: $F / R_{\max }=1.10, K_{1 / 2}$ $=28 \mu \mathrm{g} / \mathrm{ml} ; \mathrm{mAb} 1808: F / R_{\max }=0.60, K_{1 / 2}=20 \mathrm{nM}$. The results show that both anti-dystrophin antibodies give saturable binding to AChR clusters. 

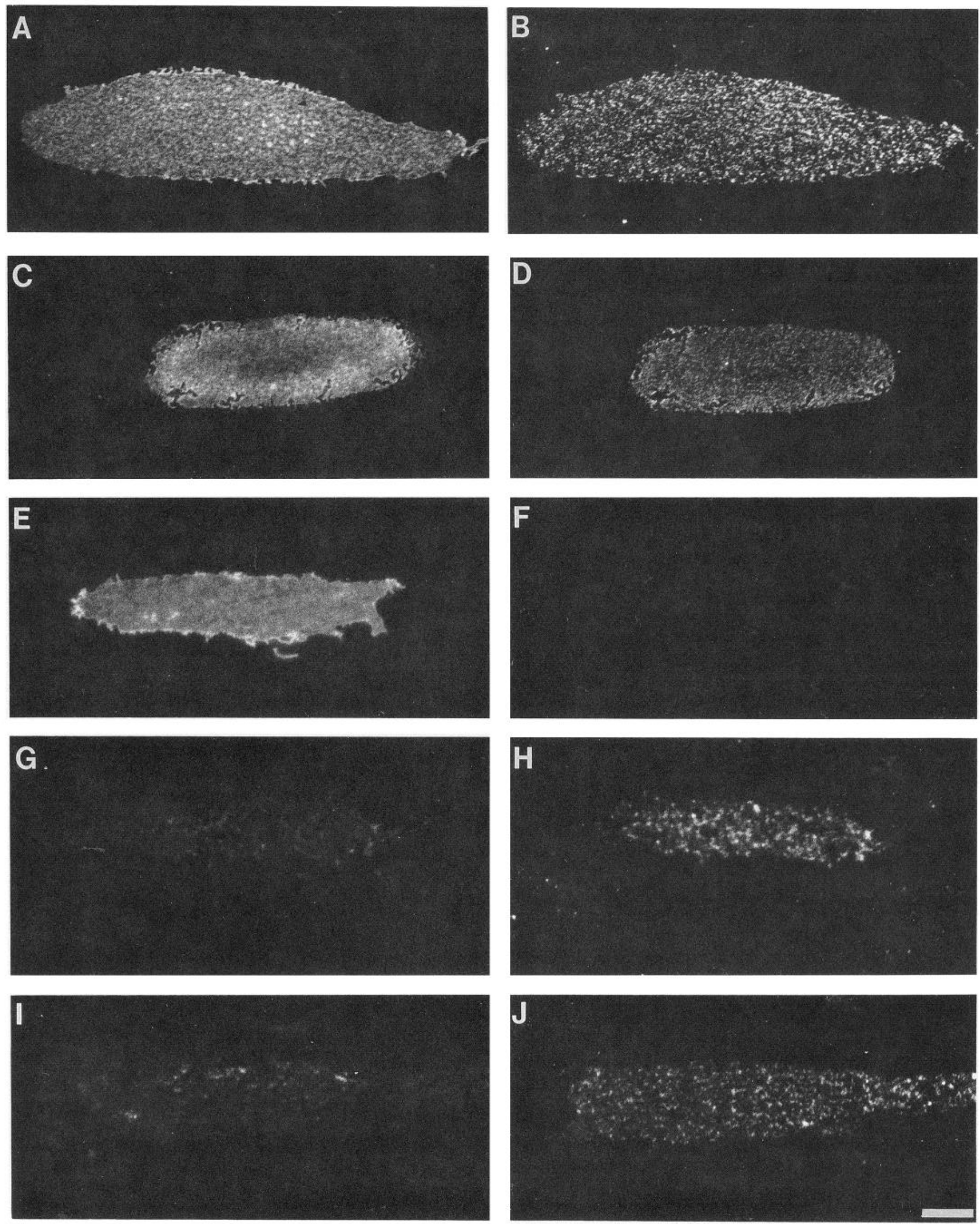

Figure 5. Domain-related organization of dystrophin is altered as AChR clusters are disrupted. Rat myotubes were prelabeled with R-BT and extracted with saponin to isolate AChR clusters. Clusters were incubated with buffer at low ionic strength for $10 \mathrm{~min}(A, B)$, buffer at pH 11 for 5 
teolysis with chymotrypsin eliminated subsequent labeling by anti-dystrophin to a significant extent (Fig. 6).

Because dystrophin also occurs in small amounts at focal contact domains of AChR clusters, we considered the possibility that its stable association with the membrane might depend on other proteins present at focal contacts. Vinculin is present in contact domains of AChR clusters isolated by shearing (Bloch and Geiger, 1981; Bloch et al., 1989), but unlike dystrophin, vinculin was almost completely removed from isolated clusters by all treatments except extraction at low ionic strength (Fig. 6 , hatched bars).

\section{Energy and $\mathrm{Ca}^{2+}$ dependence}

Previous work with cytoskeletal components associated with AChR domains has demonstrated that the organization of these components is dependent on both metabolic energy and $\mathrm{Ca}^{2+}$ (Bloch, 1986; Bloch and Morrow, 1989). To learn if the organization of dystrophin was similarly energy or $\mathrm{Ca}^{2+}$ dependent, we incubated rat myotubes in medium containing azide or depleted of $\mathrm{Ca}^{2+}$, and then isolated SAM by extraction with saponin; they were then fixed and labeled with anti-dystrophin. After disruption, clusters no longer contained linear arrays of AChRs (Fig. 5G,I). Dystrophin label was evident on the membrane, but it was no longer in linearly organized domains typical of controls (Fig. $5 H, J)$. Although we did not quantify the amount of antibody bound in these treated clusters, the labeling was qualitatively similar to that discussed above for clusters extracted with buffer A.

\section{Discussion}

Dystrophin is a peripheral protein of the sarcolemma of vertebrate skeletal muscle (Arahata et al., 1988; Bonilla et al., 1988; Watkins et al., 1988; Zubrzycka-Gaarn et al., 1988; Wakayama et al., 1989; Carpenter et al., 1990; Ohlendieck and Campbell, 1991) that resembles spectrin both in primary structure (Davison and Critchley, 1988; Koenig et al., 1988) and in molecular shape and size (Pons et al., 1990). Spectrin is a component of the membrane skeleton in erythrocytes and other cells (Bennett, 1990), and is a major structural protein in the receptor domains of AChR clusters (Bloch and Morrow, 1988; Pumplin et al., 1990). Here, we show using immunogold techniques coupled with QFDERR that dystrophin codistributes with spcctrin in the distinctive membrane skeleton of these domains. We also report that the binding of dystrophin to cluster membrane is extremely stable.

Isolated dystrophin adsorbed to mica is a 175 -nm-long, flexible, rod-shaped molecule (Pons et al., 1990). We have not seen individual filaments of this length in our preparations. Spectrin, which resembles dystrophin in sequence and predicted structure (Davison and Critchley, 1988; Koenig et al., 1988), has been found in a folded or condensed form in the membrane skeleton of the erythrocyte membrane (Ursitti et al., 1991). Thus, in situ, dystrophin may also have a folded or condensed configuration. As both dystrophin and spectrin are flexible and elastic proteins,
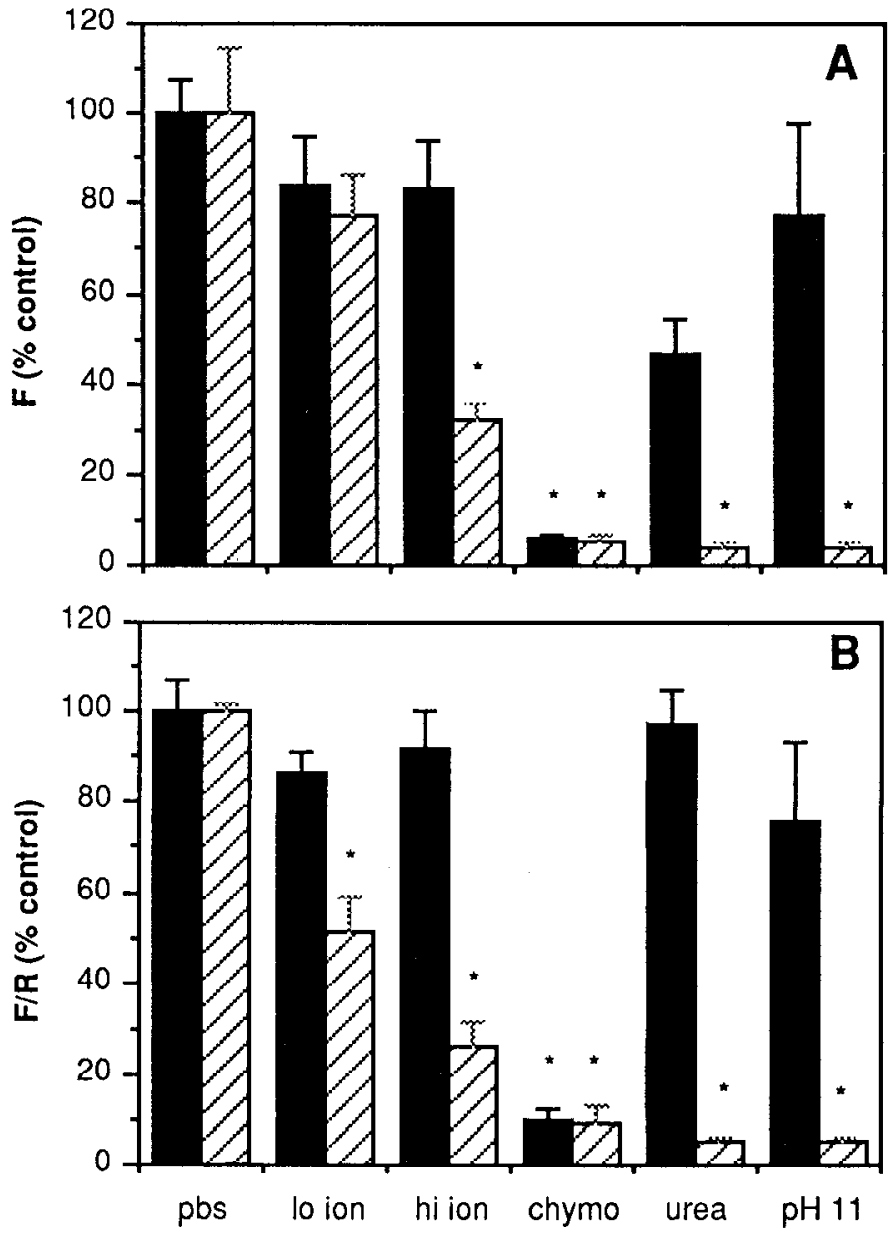

Figure 6. Effect of extractions and proteolysis on the association of dystrophin and vinculin with AChR clusters. Myotubes were labeled with R-BT and extracted with saponin or sheared to isolate AChR clusters. Isolated clusters were treated with different solutions (see below) and then fixed. All samples were labeled with mAb 1808 antidystrophin (solid bars) or with mAb 11.5 anti-vinculin (hatched bars). Bound antibody was visualized with FGAM alone (vinculin) or with biotinylated goat anti-mouse IgG followed by fluorescein-streptavidin (mAb 1808). The intensities of fluorescein fluorescence $(F)$ due to bound antibody, and of tetramethylrhodamine fluorescence $(R)$ due to bound $\mathrm{R}-\mathrm{BT}$ were made from the same area, and the ratio $F / R$ was calculated. Treatments were as follows: pbs: PBS, 5-10 min; lo ion: buffer A, 10 min; hi ion: $0.6 \mathrm{M} \mathrm{KCl,} 5 \mathrm{~min}$; chymo: chymotrypsin, $10 \mu \mathrm{g} / \mathrm{ml}$ in PBS, $5 \mathrm{~min}$; urea: $6 \mathrm{~m}$ urea, $5 \mathrm{~min} ; \mathrm{pH} 11: 50 \mathrm{~mm}$ cthylaminc-HCl, $\mathrm{pH} 11$, 5 min. All treatments were at RT. Sheep anti-dystrophin gave results similar to those reported here for $\mathrm{mAb} 1808$ (not shown). Data are mean \pm SEM as percentage of control $(n=20$ for $\mathrm{mAb} 1808 ; n=20$ for vinculin). Those values that are significantly different from PBS controls ( $p<0.05$ by ANOVA, using Scheffe $F$ test values) are indicated by an asterisk $\left({ }^{*}\right)$ over the bar.

a network composed of these proteins is likely to be flexible and elastic, also. These features may allow for the elastic deformation of membrane and associated cytoskeleton that is reflected in the diversity of filament lengths seen in the samples prepared

min $(C, D)$, and buffer containing chymotrypsin $(E, F)$ for $5 \mathrm{~min}$. Additional myotubes were incubated in culture medium containing $5 \mathrm{~mm}$ sodium azide $(G, H)$ or in culture medium without $\mathrm{Ca}^{2+}(I, J)$ for $6 \mathrm{hr}$, labeled with R-BT, and extracted with saponin to isolate AChR clusters. All samples were fixed and labeled with affinity-purified anti-dystrophin antibody, biotinylated secondary antibody, and fiuoresceinated streptavidin $(B, D, F$, $H, J$. Labeling for dystrophin was compared to labeling of AChR by R-BT in the same structures $(A, C, E, G, I)$. Dystrophin label was present but disorganized following treatments that removed or modified cytoskeletal components $(B, D)$ or interfered with cellular energy metabolism $(H)$ or lower extracellular $\mathrm{Ca}^{2+}(J)$. Dystrophin label was absent after chymotrypsin treatment $(F)$. Scale bar, $10 \mu \mathrm{m}$. 
Table 4. Removal of cytoskeletal proteins from isolated AChR clusters by different treatments ${ }^{a}$

\begin{tabular}{llllll} 
& $\begin{array}{l}\text { Low } \\
\text { ionic } \\
\text { Strength }\end{array}$ & Urea & LIS & pH 11 & $\begin{array}{l}\text { Chymo- } \\
\text { trypsin }\end{array}$ \\
\hline Actin & $-b$ & $\mathrm{ND}^{c}$ & - & - & - \\
$\beta-$ Spectrin & + & - & - & - & - \\
$43 \mathrm{kDa}$ & + & - & - & - & - \\
$58 \mathrm{kDa}$ & + & - & - & \pm & - \\
Vinculin & \pm & - & \pm & - & - \\
Dystrophin & + & + & + &,$++d$ & -
\end{tabular}

References are as follows. Actin: Bloch (1986); $\beta$-spectrin: Bloch and Morrow (1989); $43 \mathrm{kDa}$ protein and AChR: Bloch and Froehner (1987); $58 \mathrm{kDa}$ protein: Bloch et al. (1991); effects of extraction with $6 \mathrm{~m}$ urea: Krikorian and Bloch (1992).

${ }^{b}-$, removed; + , retained; \pm , removal is partial, not complete.

ND, not determined.

"Variable.

for QFDERR. Such dcformations arc expcricnced by the sarcolemma as skeletal muscle contracts and relaxes (e.g., Street, 1983).

The amino terminus of dystrophin is homologous to the actinbinding domain of $\alpha$-actinin (Koenig et al., 1988). Ervasti and Campbell (1991) have recently hypothesized that this may be the site of dystrophin's interaction with actin. Nowhere within AChR clusters does dystrophin appear to associate preferentially with actin filaments. Quantitation of gold-labeled dystrophin in QFDERR images indicates that dystrophin is approximately sixfold more prevalent within AChR domains than within actinrich focal contact domains of $\mathrm{AChR}$ clusters. Moreover, within AChR domains, dystrophin has no obvious interaction with overlying actin filaments but codistributes with spectrin instead. Rather than interacting with actin filaments, dystrophin may interact with oligomers of actin resembling those of the human erythrocyte membrane. Alternatively, it may interact homotypically, as suggested by Ervasti and Campbell (1991), or heterotypically with spectrin or with other components of cluster membrane.

Our semiquantitative fluorescence measurements suggest that dystrophin is not the major component of the membrane skeletal network in our preparation. We found that $F$ and $F / R$ values due to bound anti-AChR mAb were three- to sevenfold (mean, approximately fivefold) higher than the values for the bound anti-dystrophin $\mathrm{mAb}$. Previous experiments have suggested that AChR clusters contain one molecule each of the $43 \mathrm{kDa}$ and $58 \mathrm{kDa}$ proteins and four to seven molecules of $\beta$-spectrin for every AChR (Bloch and Froehner, 1987; Bloch and Morrow, 1989; Bloch et al., 1991). We conclude, therefore, that one copy of dystrophin is present for every $\sim 5$ copies of the AChR, 43 $\mathrm{kDa}$ and $58 \mathrm{kDa}$ proteins, and for every $\sim 20-35$ copies of $\beta$-spectrin. This ratio varies widely, as dystrophin is present at some areas but absent from other areas of the cluster membrane. Similar variability of dystrophin labeling at AChR clusters has been reported for permeabilized, intact cultured rat myotubes (Yeadon et al., 1991), suggesting that it is not due to the procedures we used to isolated AChR clusters. Thus, dystrophin is a minor and variable component of the membrane skeleton of AChR clusters.

Because dystrophin is present in low and variable amounts, it is not likely to be solely responsible for binding and immobilizing $\mathrm{AChR}$ at clusters. Our extraction and disruption experiments, showing that dystrophin is less tightly attached to other AChR-associated proteins that it is to the membrane, support this conclusion. The $43 \mathrm{kDa}$ and $58 \mathrm{kDa}$ proteins, as well as spectrin and actin, can be extracted from isolated cluster membrane with $6 \mathrm{M}$ urea (Bloch et al., 1991; Krikorian and Bloch, 1992), causing clustered AChR to disperse. By contrast, clusters so extracted retain dystrophin almost quantitatively (Fig. 6 , Table 4). These results indicate that the association of dystrophin with the cluster membrane does not depend either on $\mathrm{AChR}$ or on these peripheral membrane proteins. Dystrophin probably attaches to membrane at AChR clusters through a distinct receptor, perhaps similar to those identified in sarcolemma of adult skeletal muscle (Campbell and Kahl, 1989; Ervasti et al., 1990; Yoshida and Ozawa, 1990; Ervasti and Campbell, 1991; Ohlendieck et al., 1991b).

Although dystrophin does not appear to require any of the peripheral membrane proteins identified in $\mathrm{AChR}$ domains to bind to cluster membrane, the receptor-associated $58 \mathrm{kDa}$ protein may bind to cluster membrane in part through dystrophin. The $58 \mathrm{kDa}$ protein binds to dystrophin (Butler et al., 1992), and after extraction at alkaline $\mathrm{pH}$, some $58 \mathrm{kDa}$ protein remains associated with cluster membrane (Bloch et al., 1991; Table 4). This may be due to its ability to associate with dystrophin, which is also retained, in approximately stoichiometric amounts, following alkaline extraction.

Our results differ from previous reports showing that alkaline buffers remove dystrophin from biochemical preparations of postsynaptic membrane from Torpedo electric organ (Chang et al., 1989) and from sarcolemmal vesicles prepared from vertebrate skeletal muscle (Ervasti and Campbell, 1991; Ervasti et al., 1991; Ohlendicck and Campbell, 1991). Similarly, chaotropic agents remove dystrophin from vesicle preparations (Campbell and Kahl, 1989; Yoshida and Ozawa, 1989) but have little effect on dystrophin at AChR clusters. These discrepancies can probably be explained by differences between the membrane preparations uscd. The mcmbrane vesicles used by Campbell and his colleagues represent a subset of total sarcolemma isolated following treatment with lectins and detergents (Ervasti and Campbell, 1991; Ervasti et al., 1991; Ohlendieck and Campbell, 1991), which may weaken the binding of dystrophin. The membrane fragments we used, representing a different subset of the sarcolemma, were isolated by physical shearing or brief treatment with saponin, and are stabilized by virtue of their association with the tissue culture substrate. An additional consideration is the length of time used for extraction. Our extractions were limited to $5 \mathrm{~min}$, which was sufficient to remove most peripheral membrane proteins from cluster membrane. Campbell and coworkers (Ervasti and Campbell, 1991; Ervasti et al., 1991; Ohlendieck and Campbell, 1991) and Chang et al. (1989) used extraction times as long as hours. We have not attempted to prolong our extractions, as isolated clusters tend to be unstable in extreme alkaline conditions.

Our results also differ in some respects from those reported by Sealock et al. (1991) and Kramarcy and Sealock (1990), who studied dystrophin at the postsynaptic membrane of Torpedo electric organ, in cultured Xenopus myocytes, and at adult rat neuromuscular junctions. They report that dystrophin in cultured Xenopus myocytes is present primarily at AChR-poor areas of the membrane, especially at focal contacts. In cultured rat myotubes, we often see dystrophin in areas poor in $\mathrm{AChR}$, but these areas are usually not recognizable by immunofluorescence criteria as focal contacts either within AChR clusters (Bloch and Geiger, 1980; Bloch et al., 1989) or elsewhere on the mem- 
brane. Moreover, in samples processed by QFDERR, we saw only low levels of dystrophin labeling at focal contacts. When dystrophin is seen in a pattern, it codistributes with AChR, as it seems to do at the postsynaptic membrane of Torpedo electric organ (Sealock et al., 1991). The differences between AChR clusters of rat myotubes and Xenopus myocytes may be developmental, or they may be due to differences in the distribution of proteins that bind dystrophin. In cultured rat myotubes, for example, the $58 \mathrm{kDa}$ protein is present at $\mathrm{AChR}$ domains of the receptor clusters and not at focal contacts (Bloch et al., 1991) while its equivalent in Xenopus is also present at focal contacts (Chen et al., 1990). Our immunofluorescence results do agree with the findings of Yeadon et al. (1991), who demonstrated that dystrophin was concentrated at AChR clusters in intact rat myotubes, but that dystrophin and AChR did not have identical distributions.

In summary, we have shown that dystrophin is a component of a spectrin-rich network of filaments associated with the cytoplasmic surface of AChR-rich membrane from cultured neonatal myotubes. Dystrophin differs from all other peripheral proteins known to be in this network by its very firm attachment to the membrane, consistent with the idea that dystrophin binds to AChR-rich membrane in a distinctive manner.

\section{References}

Aggeler J, Werb Z (1982) Initial events during phagocytosis by macrophages viewed from outside and inside the cell: membrane-particle interactions and clathrin. J Cell Biol 94:613-623.

Arahata K, Ishiura E, Ishiguro T, Tsukahara T, Suhara Y, Eguchi C, Ishihara T, Nonaka I, Ozawa E, Sugita H (1988) Immunostaining of skeletal and cardiac muscle surface membrane with antibody against Duchenne muscular dystrophy peptide. Nature 333:861-863.

Avnur Z, Geiger B (1981) Substrate-attached membrane of cultured cells. Isolation and characterization of ventral cell membranes and the associated cytoskeleton. J Mol Biol 153:361-379.

Axelrod D (1981) Cell-substrate contacts illuminated by total internal reflection fluorescence. J Cell Biol 89:141-145.

Bennett V (1990) Spectrin-based membrane skeleton: a multipotential adaptor between plasma membrane and cytoplasm. Physiol Rev 70: 1029-1065.

Bloch RJ (1979) Dispersal and reformation of acetylcholine receptor clusters of cultured rat myotubes treated with inhibitors of energy metabolism. J Cell Biol 82:626-643.

Bloch RJ (1983) Acetylcholine receptor clustering in rat myotubes: requirement for $\mathrm{Ca}^{2+}$ and effects of drugs which depolymerize microtubules. J Neurosci 3:2670-2680.

Bloch RJ (1984) Isolation of acetylcholine receptor clusters in substrate-attached material from cultured rat myotubes using saponin. $\mathbf{J}$ Cell Biol 99:984-993.

Bloch RJ (1986) Actin at receptor-rich domains of isolated acetylcholine receptor clusters. J Cell Biol 102:1447-1458.

Bloch RJ, Froehner SC (1987) The relationship of the postsynaptic $43 \mathrm{~K}$ protein to acetylcholine receptors in receptor clusters isolated from cultured rat myotubes. J Cell Biol 104:645-654.

Bloch RJ, Geiger B (1980) The localization of acetylcholine receptor clusters in areas of cell-substrate contact in cultures of rat myotubes. Cell 21:25-35.

Bloch RJ, Pumplin DW (1988) Molecular events in synaptogenesis: nerve-muscle adhesion and postsynaptic differentiation. Am J Physiol 254:C245-C264.

Bloch RJ, Morrow JS (1989) An unusual $\beta$-spectrin associated with clustered acetylcholine receptors. J Cell Biol 108:481-493.

Bloch RJ, Velez M, Krikorian JG, Axelrod D (1989) Microfilaments and actin-associated proteins at sites of membrane-substrate attachment within acetylcholine receptor clusters. Exp Cell Res 182:583596.

Bloch RJ, Resneck WG, O’Neill AM, Strong JC, Pumplin DW (1991) Cytoplasmic components of acetylcholine receptor clusters of cultured rat myotubes: the $58 \mathrm{kD}$ protein. J Cell Biol 115:435-446.

Bonilla E, Samitt CE, Miranda AF, Hays AP, Salviati G, DiMauro S,
Kunkel LM, Hoffman EP, Rowland LP (1988) Duchenne muscular dystrophy: deficiency of dystrophin at the muscle cell surface. Cell 54:447-452.

Bulfield G, Siller WG, Wight PAL, Moore KJ (1984) X chromosomelinked muscular dystrophy $(m d x)$ in the mouse. Proc Natl Acad Sci USA 81:1189-1192.

Bursztajn S, McManaman JL, Appel SH (1984) Organization of acetylcholine receptor clusters in cultured rat myotubes is calcium dependent. J Cell Biol 98:507-517.

Butler MH, Douville K, Murnane AA, Kramarcy NR, Cohen JB, Sealock R, Froehner SC (1992) Association of the $M_{r} 58,000$ postsynaptic protein of electric tissue with Torpedo dystrophin and the $\mathrm{M}_{r}$ 87,000 postsynaptic protein. J Biol Chem 267:6213-6218.

Byers TJ, Kunkel LM, Watkins SC (1991) The subcellular distribution of dystrophin in mouse skeletal, cardiac and smooth muscle. J Cell Biol 115:411-421.

Campbell KP, Kahl SD (1989) Association of dystrophin and an integral membrane glycoprotein. Nature 338:259-262.

Carpenter S, Karpati G, Zubrzycka-Gaarn EE, Bulman DE, Ray PN, Worton RG (1990) Dystrophin is localized to the plasma membrane of human skeletal muscle fibers by electron-microscopic cytochemical study. Muscle Nerve 13:376-380.

Chang HW, Bock E, Bonilla E (1989) Dystrophin in electric organ of Torpedo californica homologous to that in human muscle. J Biol Chem 264:20831-20834.

Chen Q, Sealock R, Peng HB (1990) A protein homologous to the Torpedo postsynaptic $58 \mathrm{kD}$ protein is present at the myotendinous junction. J Cell Biol 110:2061-2071.

Craig SW, Pardo JV (1983) Gamma actin, spectrin and intermediate filament proteins colocalize with vinculin at costameres, myofibrilto-sarcolemma attachment sites. Cell Motil 3:449-462.

Cullen MJ, Walsh J, Nicholson LVB, Harris JB (1990) Ultrastructural localization of dystrophin in human muscle by using gold immunolabclling. Proc R Soc Lond [Biol] 240:197-210.

Davison MD, Critchley DR (1988) $\alpha$-Actinins and the DMD protein contain spectrin-like repeats. Cell 52:159-160.

Ervasti JM, Campbell KP (1991) Membrane organization of dystrophin glycoprotein complex. Cell 66:1121-1131.

Ervasti JM, Ohlendieck K, Kahl SD, Gaver MG, Campbell KP (1990) Deficiency of a glycoprotein component of the dystrophin complex in dystrophic muscle. Nature 345:315-319.

Ervasti JM, Kahl SD, Campbell KP (1991) Purification of dystrophin from skeletal muscle. J Biol Chem 266:9161-9165.

Fardeau M, Tome FMS, Collin H, Augier N, Pons F, Leger J, Leger J (1990) Présence d'une protéine de type dystrophine au niveau de la jonction neuromusculaire dans la dystrophie musculaire de Duchenne et la souris mutante "mdx." C R Acad Sci [C] (Paris) 311:197-204.

Frochncr SC, Douville K, Klink S, Culp WJ (1983) Monoclonal antibodies to cytoplasmic domains of the acetylcholine receptor. J Biol Chem 258:7112-7120.

Heuser JE, Kirchner MW (1980) Filament organization revealed in platinum replicas of freeze-dried cytoskeletons. J Cell Biol 86:212234.

Hoffman EP, Kunkel LM (1989) Dystrophin abnormalities in Duchenne/Becker muscular dystrophy. Neuron 2:1019-1029.

Hoffman EP, Brown RH Jr, Kunkel LM (1987) Dystrophin: the protein product of the Duchenne muscular dystrophy locus. Cell 51:919928.

Hoffman EP, Fishbeck KH, Brown RH, Johnson M, Medori R, Loike JD, Harris JB, Waterston R, Brooke M, Specht L, Kupsky W, Chamberlain J, Caskey CT, Shapiro F, Kunkel LM (1988) Characterization of dystrophin in musclc-biopsy specimens from patients with Duchenne's or Becker's muscular dystrophy. N Engl J Med 318:13631368.

Jasmin BJ, Cartaud A, Ludosky MA, Changeux JP, Cartaud J (1990) Asymmetric distribution of dystrophin in developing and adult Torpedo marmorata electrocyte: evidence for its association with the acetylcholine receptor-rich membrane. Proc Natl Acad Sci USA 87: 3938-3941.

Johnson GD, Davidson RS, McNamee KC, Russell G, Goodwin D, Holborow EJ (1982) Fading of immunofluorescence during microscopy: a study of the phenomenon and its remedy. J Immunol Methods 55:231-242.

Khurana TS, Hoffman EP, Kunkel LM (1990) Identification of chromosome 6 -encoded dystrophin related protein. J Biol Chem 265 : $16717-16720$. 
Koenig M, Monaco AP, Kunkel LM (1988) The complete sequence of dystrophin predicts a rod-shaped cytoskeletal protein. Cell 53:219228.

Kramarcy NR, Sealock R (1990) Dystrophin as a focal adhesion protein: colocalization with talin and the $M_{r} 48,000$ sarcolemmal protein in cultured Xenopus muscle. FEBS Lett 272:171-174.

Krikorian JG, Bloch RJ (1992) Treatments that extract the 43K protein from acetylcholine receptor clusters modify the conformation of cytoplasmic domains of all subunits of the receptor. J Biol Chem 267: 9118-9128.

Land BR, Podleski TR, Salpeter EE, Salpeter MM (1977) Acetylcholine receptor distribution on myotubes in culture correlated to acctylcholine sensitivity. J Physiol (Lond) 269:155-176.

Lidov HGW, Byers TJ, Watkins SC, Kunkel LM (1990) Localization of dystrophin to postsynaptic regions of central nervous system cortical neurons. Nature 348:725-728.

Love DR, Hill DF, Dickson G, Spurr NK, Byth BC, Marsden RF, Walsh FS, Edwards YH, Davies KE (1989) An autosomal transcript in skeletal muscle with homology to dystrophin. Nature 339:55-58.

Nelson WJ, Lazarides E (1984) Goblin (ankyrin) in striated muscle: identification of the potential membrane receptor for erythroid spectrin in muscle cells. Proc Natl Acad Sci USA 81:3292-3296.

Ohlendieck K, Campbell KP (1991) Dystrophin constitutes 5\% of membrane cytoskeleton in skeletal muscle. FEBS Lett 283:230-234.

Ohlendieck K, Ervasti JM, Matsumura K, Kahl SD, Leveille CJ, Campbell KP (1991a) Dystrophin-rclatcd protcin is localizcd to ncuromuscular junctions of adult skeletal muscle. Neuron 7:499-508.

Ohlendieck K, Ervasti JM, Snook JB, Campbell KP (1991b) Dystrophin-glycoprotein complex is highly enriched in isolated skeletal muscle sarcolemma. J Cell Biol 112:135-148.

Pardo JV, Siliciano JD, Craig SW (1983a) Vinculin is a component of an extensive network of myofibril-sarcolemma attachment regions in cardiac muscle fibers. J Cell Biol 97:1081-1088.

Pardo JV, Siliciano JD, Craig SW (1983b) A vinculin-containing cortical lattice in skeletal muscle: transverse lattice elements ("costameres") mark sites of attachment between myofibrils and sarcolemma. Proc Natl Acad Sci USA 80:1008-1012.

Pons F, Augier N, Heilig R, Leger J, Mornet D, Leger JJ (1990) Isolated dystrophin molecules as seen by electron microscopy. Proc Natl Acad Sci USA 87:7851-7855.

Pons F, Augier N, Leger JOC, Robert A, Tome FMS, Fardeau M, Voit T, Nicholson LVB, Mornet D, Leger JJ (1991) A homologue of dystrophin is expressed at the neuromuscular junctions of normal individuals and DMD patients, and of normal and $m d x$ mice. Immunologic evidence. FEBS Lett 282:161-165.

Porter GA, Dmytrenko GM, Winkelmann JC, Bloch RJ (1992) Dystrophin colocalizes with $\beta$-spectrin in distinct subsarcolemmal domains in mammalian skeletal muscle. J Cell Biol 117:997-1005.

Pumplin DW (1989) Acetylcholine receptor clusters of rat myotubes have at least three domains with distinctive cytoskeletal and membrane components. J Cell Biol 109:739-753.

Pumplin DW, Bloch RJ (1983) Lipid domains of acetylcholine recep- tor clusters detected with saponin and filipin. J Cell Biol 97:10431054.

Pumplin DW, Bloch RJ (1990) Clathrin-coated membrane: a distinct membrane domain in acetylcholine receptor clusters of rat myotubes. Cell Motil Cytoskel 15:121-134.

Pumplin DW, Luther PW, Samuelsson SJ, Ursitti JA, Strong J (1990a) Quick-freeze, deep-etch, replication of cells in monolayers. J Electron Microsc Tech 14:342-347.

Pumplin DW, Strong JC, Krikorian JG, Porter GA, Winkelmann JC (1990b) Localization of $58 \mathrm{~K}$ protein and $\beta$-spectrin by immunogold labeling of acetylcholine receptor clusters. J Cell Biol 111:165a.

Ravdin P, Axclrod D (1977) Fluorcscent tetramethyl rhodaminc dcrivatives of $\alpha$-bungarotoxin: preparation, separation, and characterization. Anal Biochem 80:585-592; erratum, 83:336.

Sealock R, Butler MH, Kramarcy NR, Gao K-X, Murnane AA, Douville K, Froehner SC (1991) Localization of dystrophin relative to acetylcholine receptor domains in electric tissue and adult and cultured skeletal muscle. J Cell Biol 113:1133-1144.

Shimizu T, Matsumura K, Sunada Y, Mannen T (1989) Dense immunostaining on both neuromuscular and myotendon junctions with an anti-dystrophin monoclonal antibody. Biomed Res 10:405-409.

Spudich JA, Watt S (1971) Regulation of rabbit skeletal muscle contraction. I. Biochemical studies of the interaction of the tropomyosintroponin complex with actin and the proteolytic fragments of myosin. J Biol Chem 256:4866-4871.

Strect SF (1983) Lateral transmission of tension in frog myofibers: a myofibrillar network and transverse cytoskeletal connections are possible transmitters. J Cell Physiol 114:346-364.

Ursitti JA, Pumplin DW, Wade JB, Bloch RJ (1991) Ultrastructure of the human erythrocyte cytoskeleton and its attachments to the membrane. Cell Motil Cytoskel 19:227-243.

Wakayama Y, Shibuya S (1991) Gold-labelled dystrophin molecule in muscle plasmalemma of $\mathrm{mdx}$ control mice as seen by electron microscopy of deep etching replica. Acta Neuropathol (Berl) 82:178184.

Wakayama Y, Jimi T, Misugi N, Kumagai T, Miyake S, Shibuya S, Miike T (1989) Dystrophin immunostaining and freeze-fracture studies of muscles of patients with early stage amyotrophic lateral sclerosis and Duchenne muscular dystrophy. J Neurol Sci 91:191205.

Watkins SC, Hoffman EP, Slayter HS, Kunkel LM (1988) Immunoelectron microscopic localization of dystrophin in myofibres. Nature 333:863-866.

Yeadon JE, Lin H, Dyer SM, Burden SJ (1991) Dystrophin is a component of the subsynaptic membrane. J Cell Biol 115:1069-1076.

Yoshida M, Ozawa E (1990) Glycoprotein complex anchoring dystrophin to sarcolemma. J Biochem 108:748-752.

Zubrzycka-Gaarn EE, Bulman DE, Karpati G, Burghes AHM, Belfall B, Hajklamut H, Talbot J, Hodges RS, Ray PN, Worton RG (1988) The Duchenne muscular dystrophy gene product is localized in sarcolemma of human skeletal muscle. Nature 333:466-469. 